Supporting Information

Visualizing the underlying signaling pathway related with nitric oxide and glutathione in cardiovascular diseases therapy by a sequentially-activated fluorescent probe

Xiao-Xiao Chen ${ }^{a}$, Li-Ya Niu ${ }^{a^{*}}$, Qing-Zheng Yang ${ }^{a^{*}}$

${ }^{\text {a }}$ Key Laboratory of Radiopharmaceuticals, Ministry of Education, College of Chemistry, Beijing Normal University, Beijing 100875, P. R. China.

\title{
CONTENTS
}

Synthesis and Characterization of 1 ................................................................

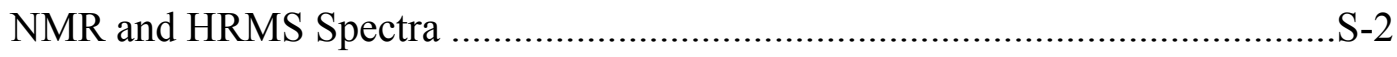

Spectrographic Properties of 1 ....................................................................... S-5

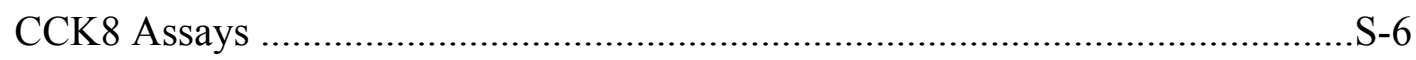

Confocal Fluorescence Imaging ……………………………............................. S-6 


\section{Synthesis and Characterization of 1}

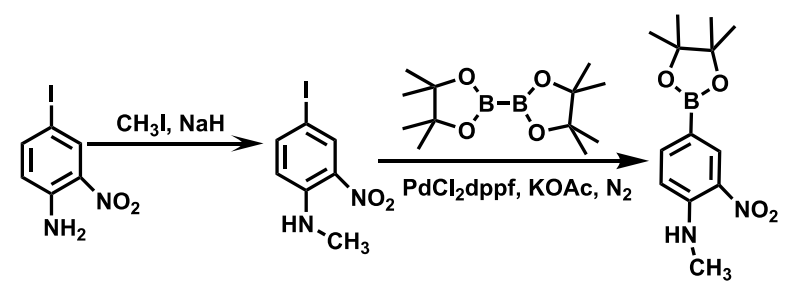

$1 \mathrm{a}$

$1 b$
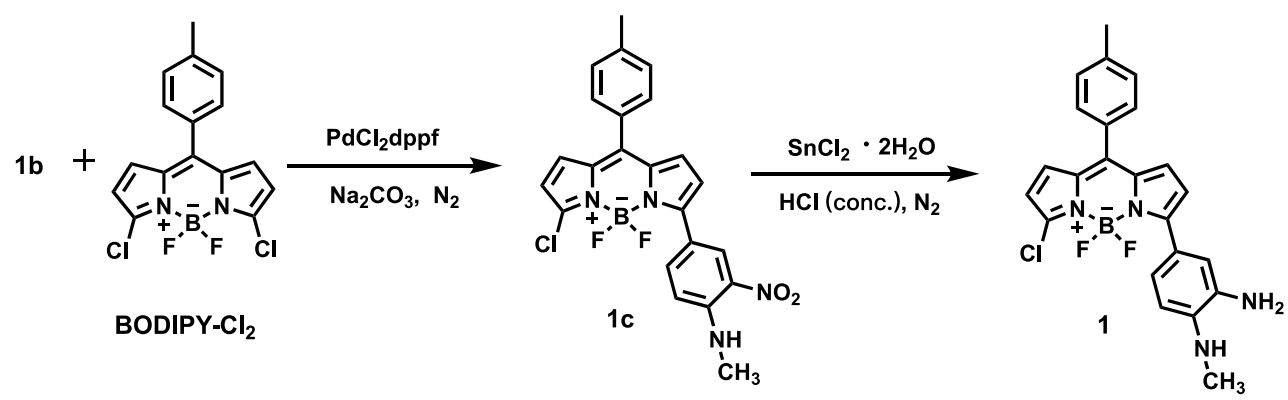

Figure S1. Synthetic route of probe 1

BODIPY $-\mathbf{C l}_{\mathbf{2}}$ was prepared following the previous methods ${ }^{1}$.

1a: 4-iodo-2-nitroaniline (2.0 g) and sodium hydride ( $0.33 \mathrm{~g}, 60 \%$ dispersion in mineral oil) were dissolved in dry DMF $(20 \mathrm{~mL})$. Then, iodomethane $(470 \mu \mathrm{L})$ was added to the mixture dropwise at $0{ }^{\circ} \mathrm{C}$. The resulting mixture was then stirred for 2 hours. The reaction mixture was poured into water, and the mixture was extracted with ethyl acetate for 3 times. The organic layer was dried over anhydrous sodium sulfate, filtered and evaporated under reduced pressure. The crude residue was purified by column chromatography on silica gel (PE : DCM $=10: 1)$ to yield $1 \mathbf{a}(0.98 \mathrm{~g}, 47 \%$ yield $) .{ }^{1} \mathrm{H}$ NMR $\left(600 \mathrm{MHz}, \mathrm{CDCl}_{3}\right) \delta 6.99(\mathrm{dd}, J=8.4,2.1 \mathrm{~Hz}), 6.84(\mathrm{~d}, J=2.1 \mathrm{~Hz}), 6.43(\mathrm{~d}, J=$ $8.4 \mathrm{~Hz}), 4.21(\mathrm{~s}), 3.83(\mathrm{~s}), 2.84(\mathrm{~s})$.

1b: $1 \mathrm{a}(0.50 \mathrm{~g}, 1.8 \mathrm{mmol})$, bis(pinacolato)diboron (0.68 g, $2.7 \mathrm{mmol}), \mathrm{PdCl}_{2}(\mathrm{dppf})$ $(0.039 \mathrm{~g}, 0.057 \mathrm{mmol})$, and KOAc $(0.52 \mathrm{~g}, 5.4 \mathrm{mmol})$ were dissolved in dry DMF (30 $\mathrm{mL}$ ) and then the reaction mixture was stirred at $80{ }^{\circ} \mathrm{C}$ overnight under nitrogen atmosphere. After cooling to room temperature, the reaction mixture was poured into brine and extracted by ethyl acetate for 3 times. The organic layer was dried over anhydrous sodium sulfate, filtered and evaporated under reduced pressure. The crude residue was purified by column chromatography on silica gel (PE: $\mathrm{DCM}=1: 3$ ) to obtain $\mathbf{1 b}$ as a yellowish solid $\left(0.20 \mathrm{~g}, 40 \%\right.$ yield). ${ }^{1} \mathrm{H} \mathrm{NMR}\left(600 \mathrm{MHz}, \mathrm{CDCl}_{3}\right) \delta 8.62$ $(\mathrm{d}, J=1.4 \mathrm{~Hz}), 8.18(\mathrm{~d}, J=1.4 \mathrm{~Hz}), 7.81(\mathrm{dd}, J=8.6,0.9 \mathrm{~Hz}), 6.79(\mathrm{~d}, J=8.6 \mathrm{~Hz})$, $3.03(\mathrm{~d}, J=5.1 \mathrm{~Hz}), 1.32(\mathrm{~s})$.

1c: BODIPY-Cl 2 (0.35 g, $1.1 \mathrm{mmol}), \mathrm{PdCl}_{2}$ (dppf) (0.022 g, $\left.0.028 \mathrm{mmol}\right), \mathrm{Na}_{2} \mathrm{CO}_{3}(1.1$ $\mathrm{g}, 10 \mathrm{mmol})$ and $1 \mathrm{~b}(0.28 \mathrm{~g}, 1.0 \mathrm{mmol})$ were dissolved in a mixed solvent (toluene $/ \mathrm{EtOH} / \mathrm{H}_{2} \mathrm{O}, 4 / 1 / 2$ ) under nitrogen atmosphere. The reaction mixture was stirred at $80^{\circ} \mathrm{C}$ overnight. The resulting residue was diluted with dichloromethane and then washed with brine. The organic layer was dried over anhydrous sodium sulfate, 
filtered and evaporated under reduced pressure. The crude product was purified by column chromatography on silica gel (PE : $\mathrm{DCM}=1: 2)$ to give $\mathbf{1 c}$ as a red soild $(0.080$ g, $17 \%$ yield). ${ }^{1} \mathrm{H}$ NMR (400 MHz, $\left.\mathrm{CDCl}_{3}\right) \delta 8.67$ (d, $\left.J=1.6 \mathrm{~Hz}\right), 8.43(\mathrm{~d}, J=8.6 \mathrm{~Hz}$ ), $8.31(\mathrm{~d}, J=3.6 \mathrm{~Hz}), 7.42(\mathrm{~d}, J=7.8 \mathrm{~Hz}), 7.33(\mathrm{~d}, J=7.7 \mathrm{~Hz}), 6.98(\mathrm{dd}, J=20.9,6.6$ $\mathrm{Hz}), 6.78(\mathrm{dd}, J=9.0,4.0 \mathrm{~Hz}), 6.38(\mathrm{~d}, J=3.9 \mathrm{~Hz}), 3.12(\mathrm{~d}, J=5.0 \mathrm{~Hz}), 2.48(\mathrm{~s}) .{ }^{13} \mathrm{C}$ NMR $\left(100 \mathrm{MHz}, \mathrm{CDCl}_{3}\right) \delta 158.38,146.98,143.27,141.35,141.06,137.19,133.29$, 132.87, 131.72 , 130.66, 129.25, 128.59, 120.97, 119.42, 117.64, 113.87, 29.96, 21.53. ESI-HRMS: $[\mathrm{M}+\mathrm{Na}]^{+}$: calcd 489.10716, Found 489.10733.

1: $0.080 \mathrm{~g}$ 1c was dissolved in $20 \mathrm{~mL} \mathrm{~N}, \mathrm{~N}$-dimethylformamide, and followed by the addition of stannous chloride $(0.34 \mathrm{~g}, 1.5 \mathrm{mmol})$ and $0.50 \mathrm{~mL}$ concentrated hydrochloric acid under nitrogen atmosphere. The reaction was stirred under room temperature for overnight. The mixture was neutralized with aqueous $\mathrm{NaHCO}_{3}$ and extracted with dichloromethane. The organic layer was dried over anhydrous $\mathrm{MgSO}_{4}$, concentrated and purified by column chromatography on silica gel (DCM : $\mathrm{MeOH}=1: 3)$ to obtain 1 (0.020 g, 27\% yield). ${ }^{1} \mathrm{H}$ NMR (400 MHz, ) $\delta 7.65-7.57$ (m), 7.40 (d, $\left.J=8.0 \mathrm{~Hz}\right), 7.29$ $(\mathrm{d}, J=7.9 \mathrm{~Hz}), 6.89$ (d, $J=4.5 \mathrm{~Hz}), 6.75(\mathrm{~d}, J=4.5 \mathrm{~Hz}), 6.68(\mathrm{~d}, J=8.9 \mathrm{~Hz}), 6.64$ (d, $J=3.7 \mathrm{~Hz}), 6.30$ (d, $J=3.9 \mathrm{~Hz}), 3.35$ (s), 2.93 (s), 2.45 (s). ${ }^{13} \mathrm{C}$ NMR (100 MHz, $\left.\mathrm{CDCl}_{3}\right) \delta 162.60,142.82,140.73,140.42,138.13,137.85,132.88,131.13,130.74$, 130.52, 129.11, 125.13, 122.25, 120.70, 118.36, 109.69, 30.51, 21.51. ESI-HRMS: $[\mathrm{M}+\mathrm{Na}]^{+}$: calcd 459.13298, Found 459.13376.

\section{NMR and HRMS Spectra}

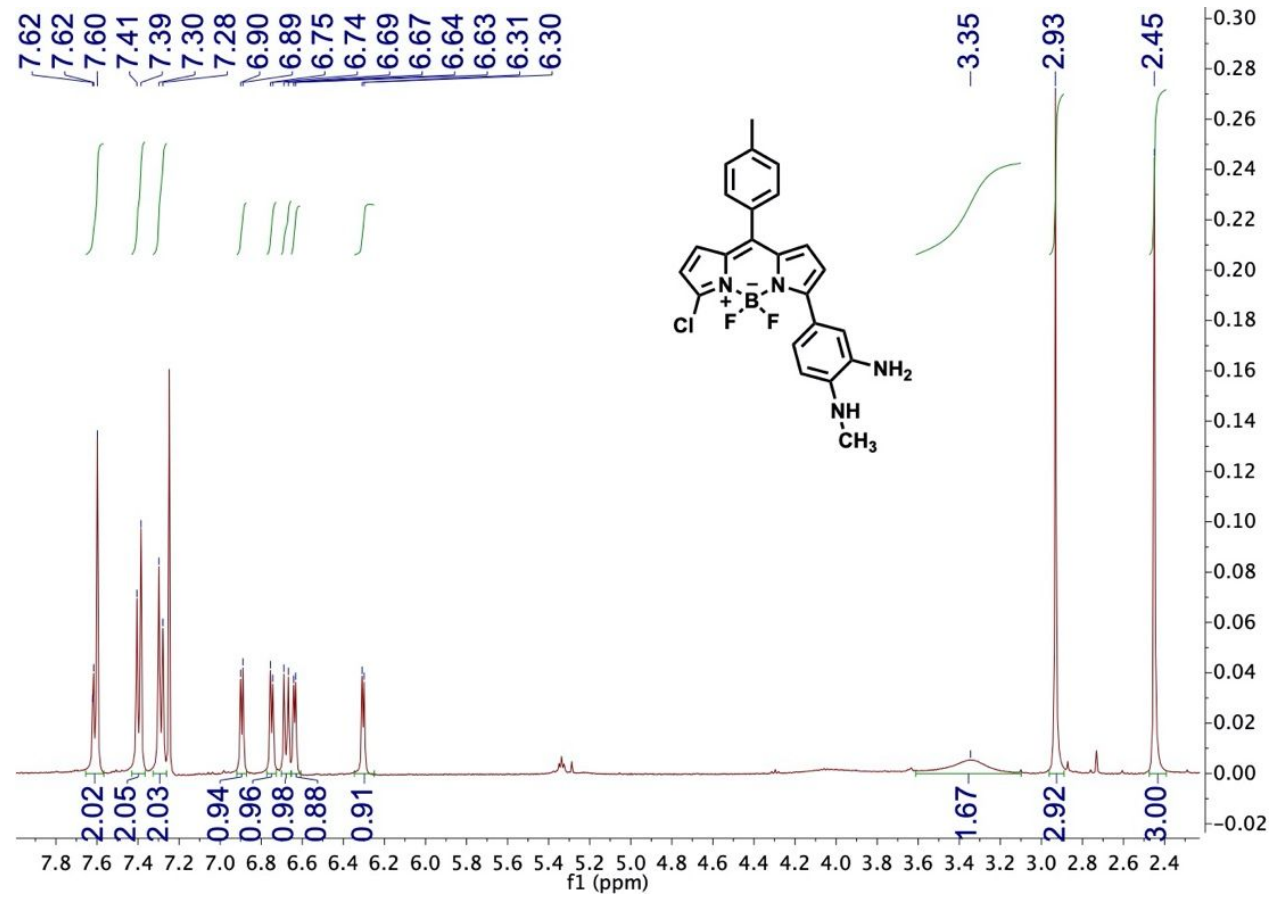

Figure S2. ${ }^{1} \mathrm{H}$ NMR spectrum of $1\left(400 \mathrm{M}, \mathrm{CDCl}_{3}\right)$ 


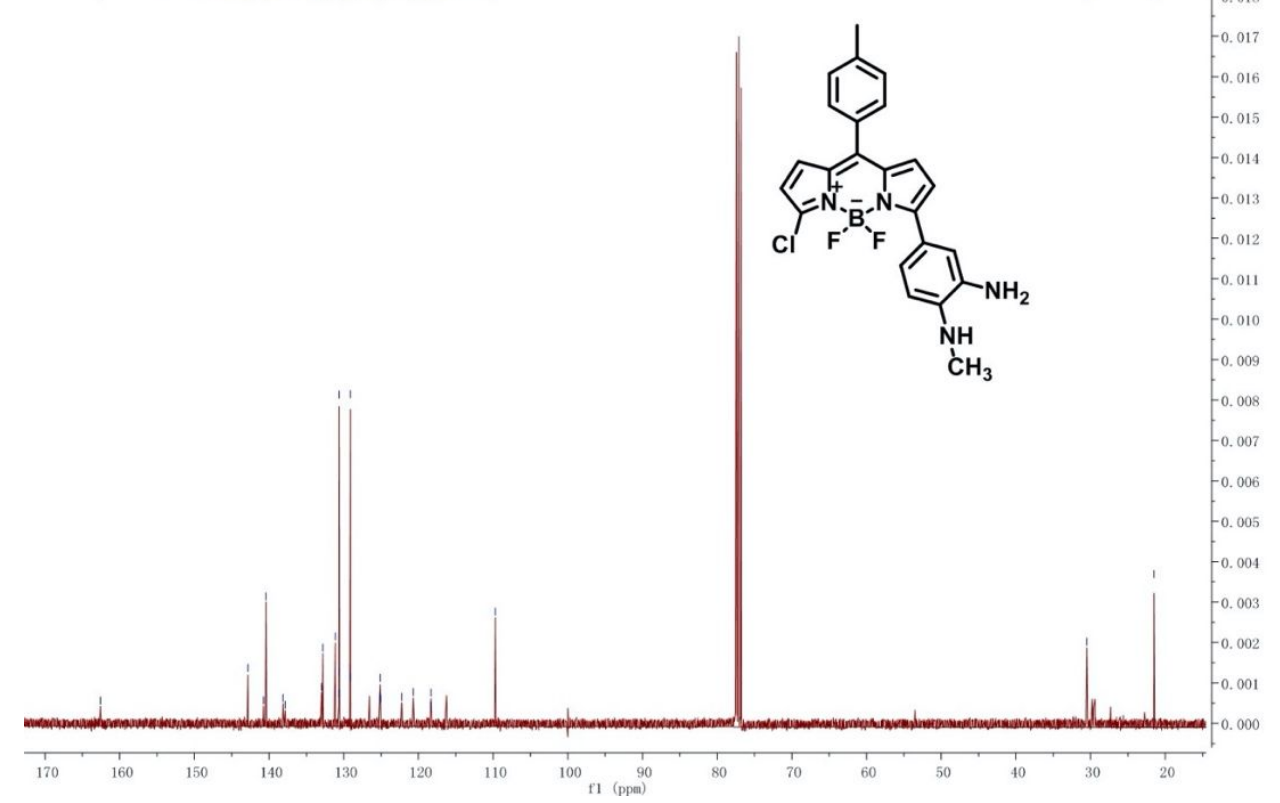

Figure S3. ${ }^{13} \mathrm{C}$ NMR spectrum of $\mathbf{1}\left(100 \mathrm{M}, \mathrm{CDCl}_{3}\right)$

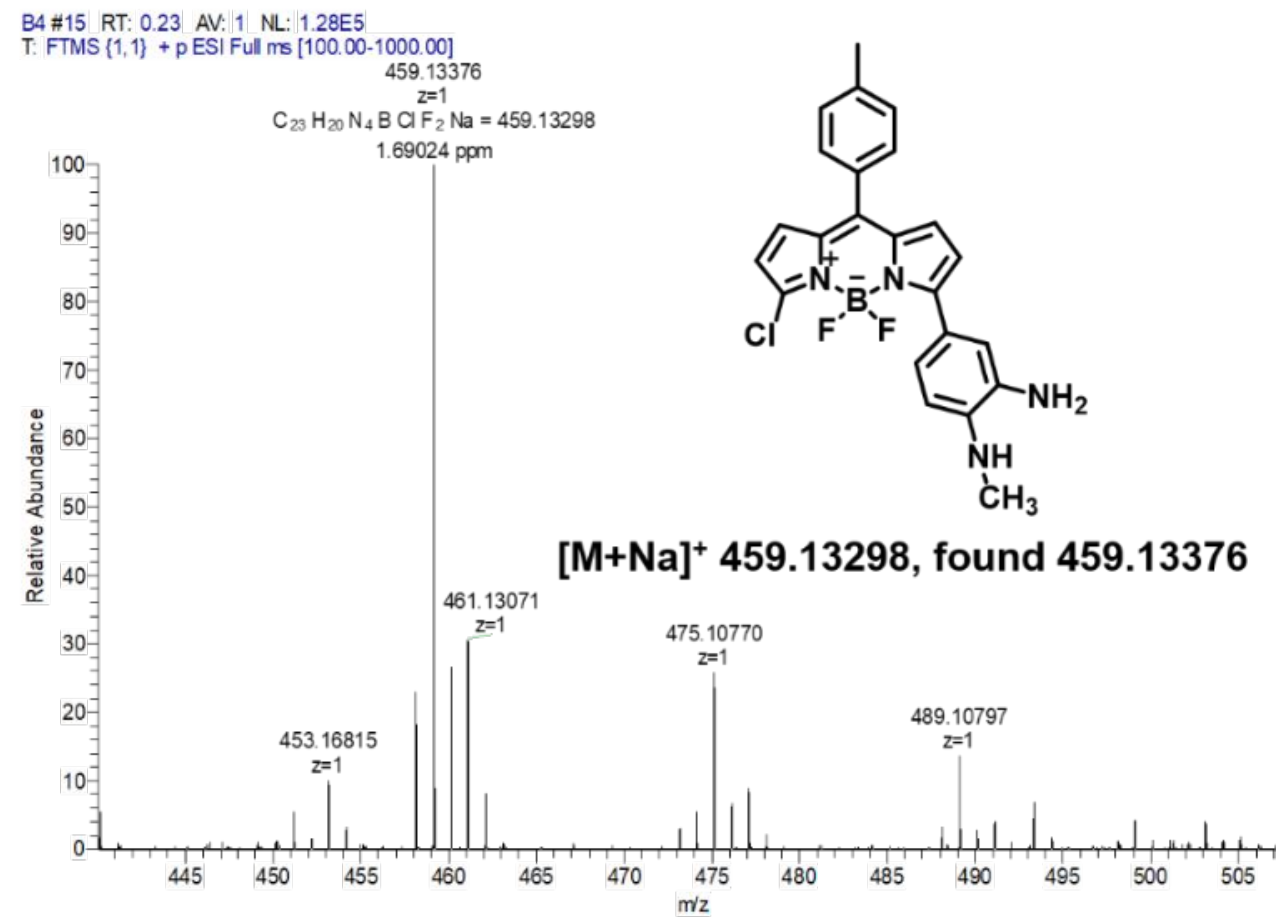

Figure S4. ESI-HRMS spectrum of $\mathbf{1}$. 


$$
\begin{gathered}
\mathrm{z}=1 \\
\mathrm{C}_{23} \mathrm{H}_{18} \mathrm{~N}_{5} \mathrm{~B} \mathrm{Cl} \mathrm{F} \mathrm{F}_{2}=448.13064
\end{gathered}
$$

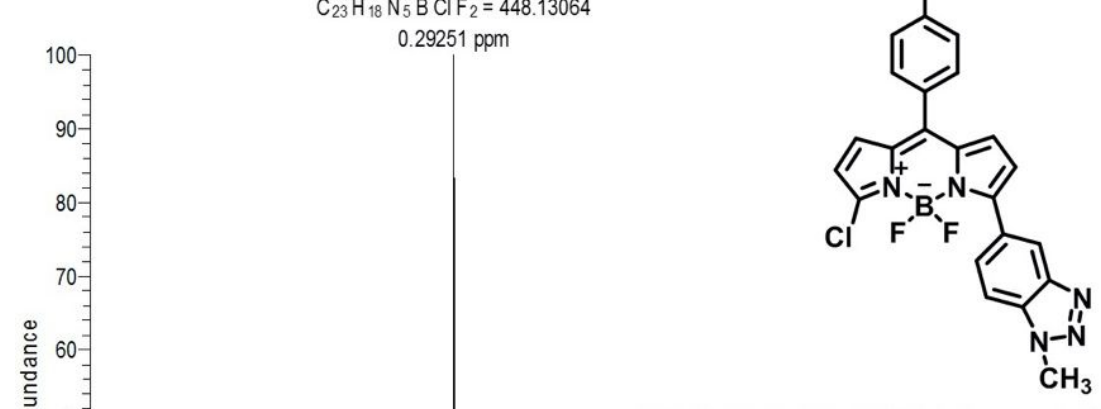

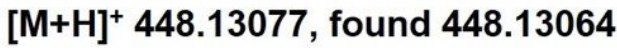

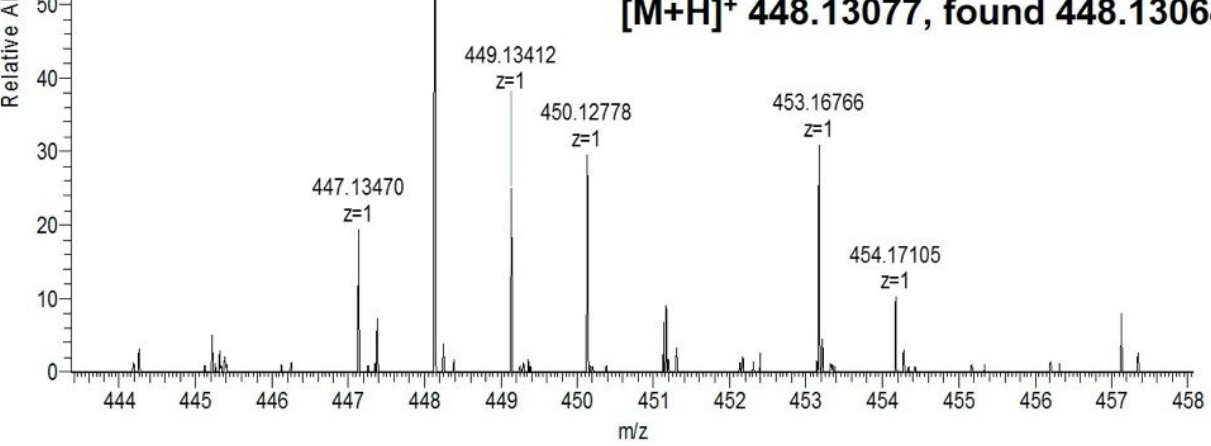

Figure S5. ESI-HRMS spectrum of 1-NO.

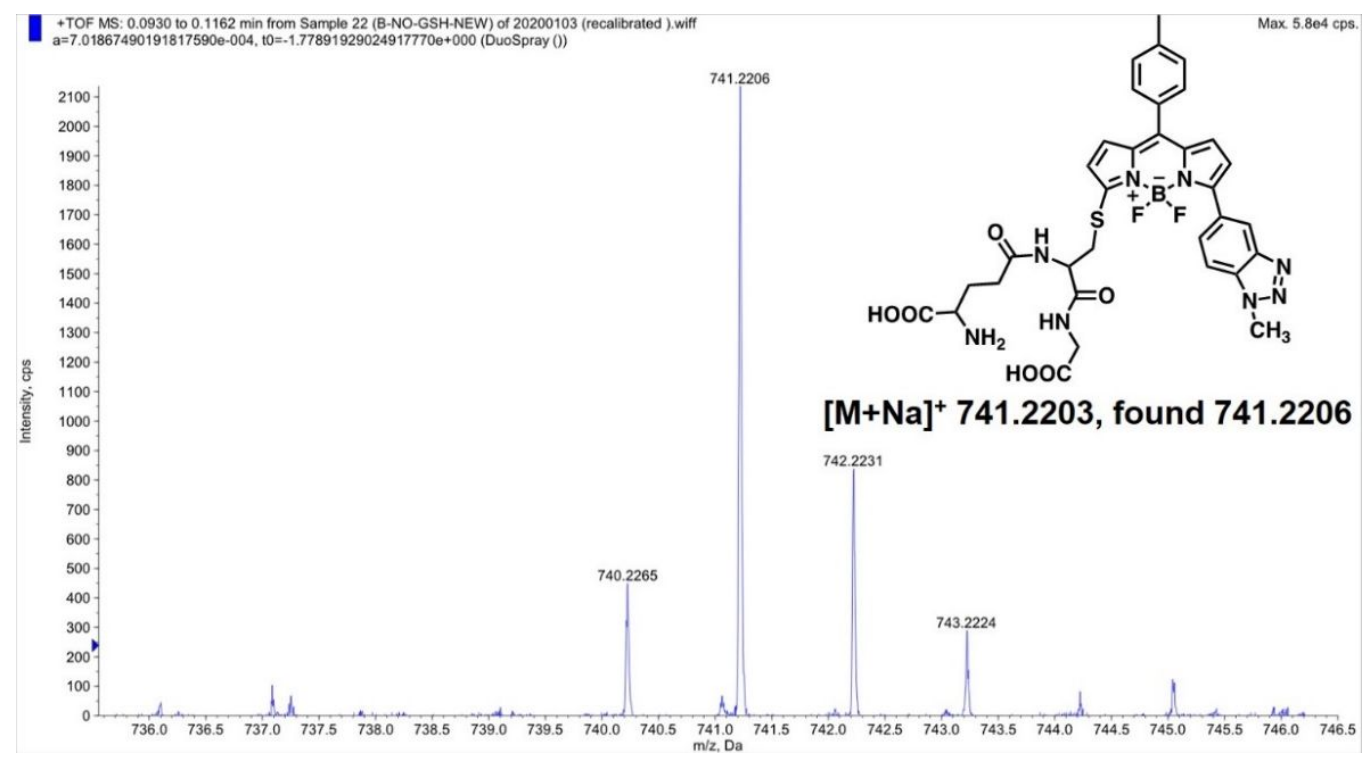

Figure S6. ESI-HRMS spectrum of 1-NO-GSH.

\section{Spectrographic Properties of 1}


(a)

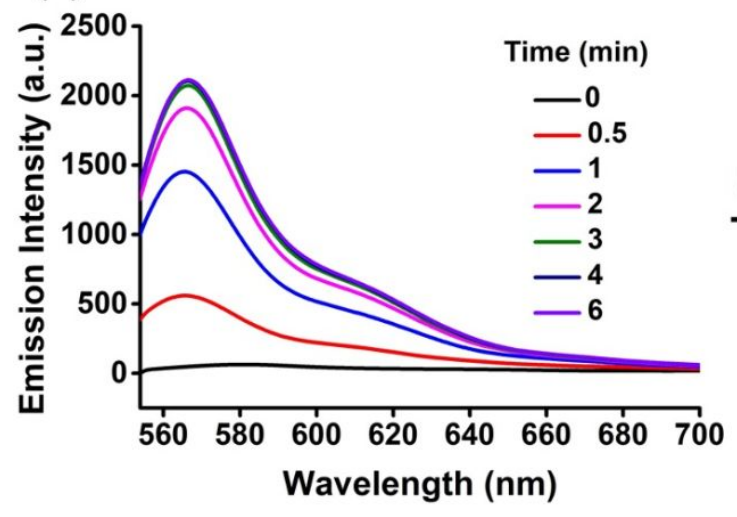

(b)

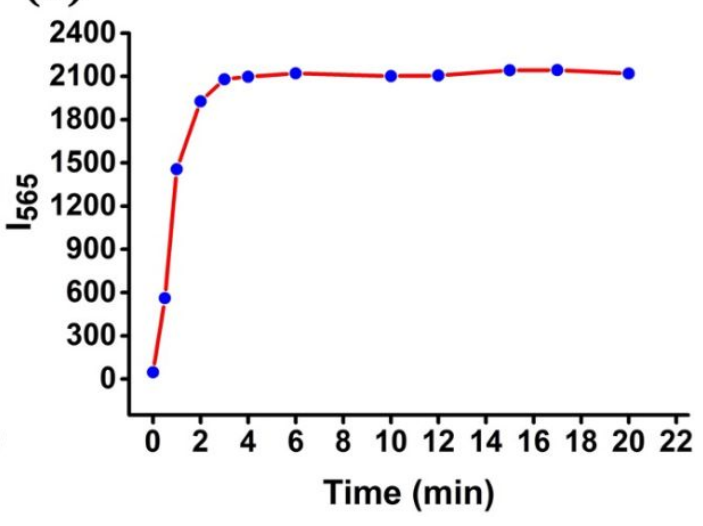

Figure S7. (a) Time-dependent fluorescence spectra of $1(10 \mu \mathrm{M})$ upon addition of DEA NONOate $(200 \mu \mathrm{M})$. (b) Time-dependent fluorescence changes of 1 toward DEA $\cdot$ NONOate $(200 \mu \mathrm{M}) \cdot \lambda_{\mathrm{ex}}=532 \mathrm{~nm}, \lambda_{\mathrm{em}}=565 \mathrm{~nm}$.

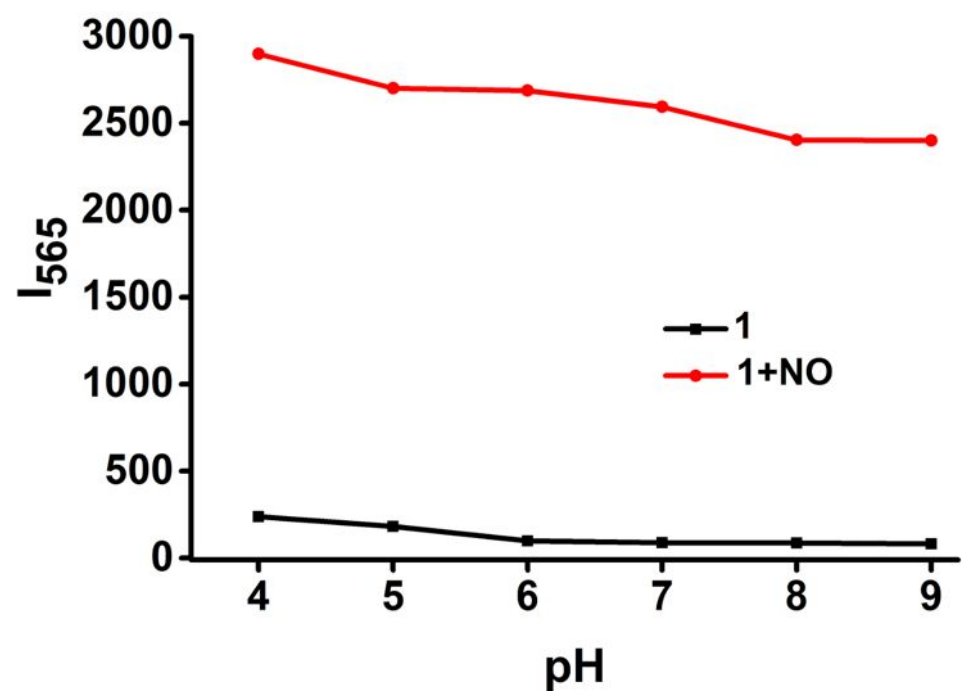

Figure S8. The emission intensities at $565 \mathrm{~nm}$ for $\mathbf{1}(10 \mu \mathrm{M})$ in the absence and presence of DEA $\cdot$ NONOate $(200 \mu \mathrm{M})$ at varied $\mathrm{pH}$ values. Each Spectrum was recorded in PBS buffer $\left(10 \mathrm{mM}\right.$, $\mathrm{pH} 7.4$, containing $\left.25 \% \mathrm{CH}_{3} \mathrm{CN}\right)$ after 30 min addition of DEA $\cdot$ NONOate at $37^{\circ} \mathrm{C} . \lambda_{\mathrm{ex}}=532 \mathrm{~nm}, \lambda_{\mathrm{em}}=565 \mathrm{~nm}$.

\section{CCK8 Assays}




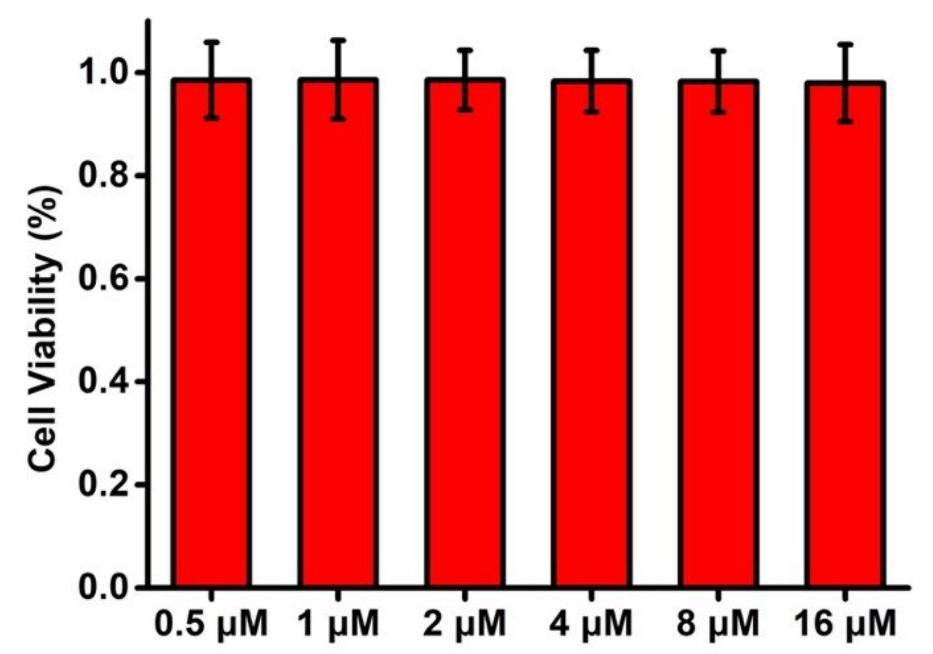

Figure S9. Cell viability of HUVECs to different concentrations of $\mathbf{1}$ for $12 \mathrm{~h}$ incubation at $37^{\circ} \mathrm{C}$ in a humidified atmosphere of $5 \% \mathrm{CO}_{2}$.

\section{Confocal Fluorescence Imaging}

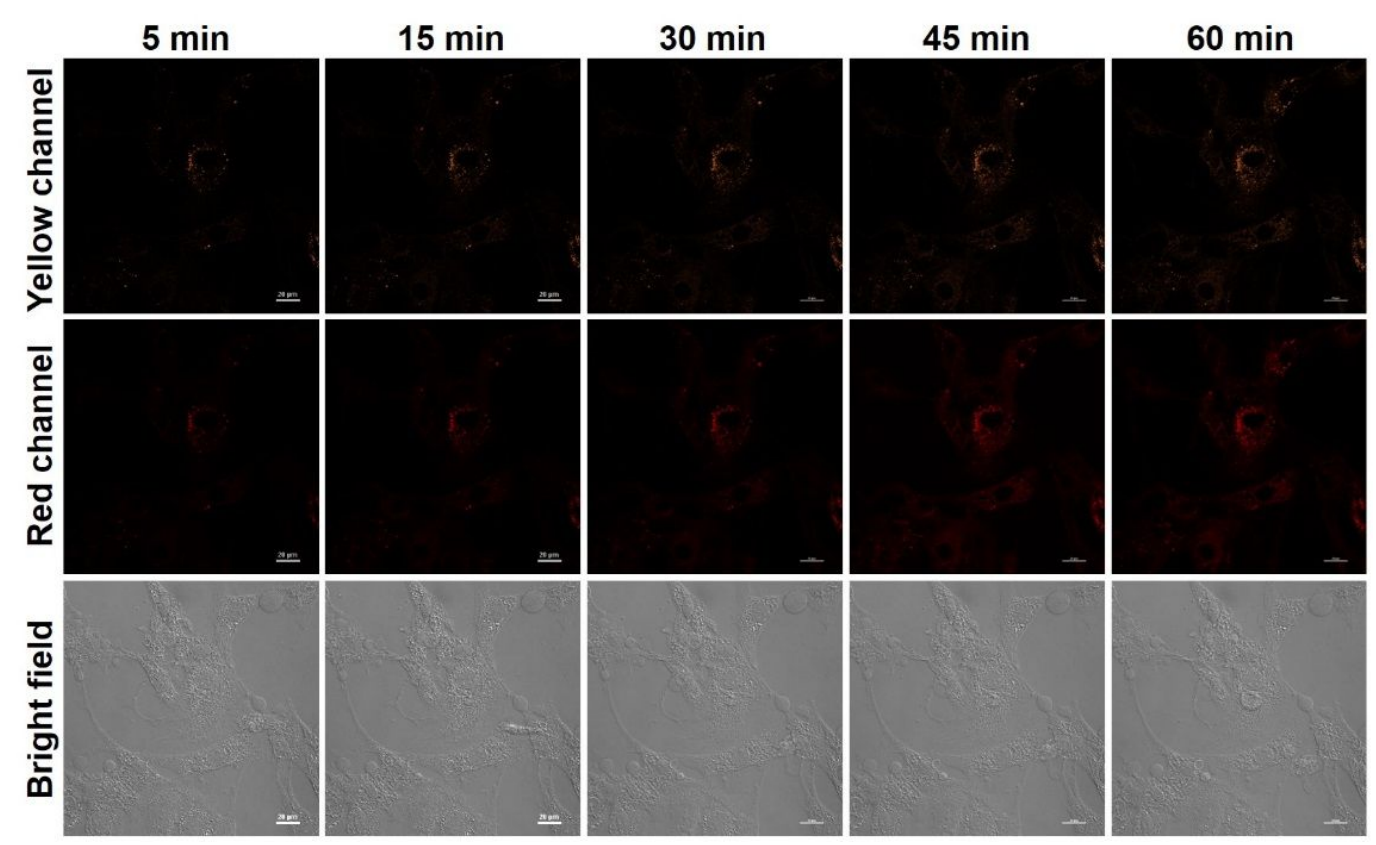

Figure S10. Real-time confocal fluorescence images of HUVECs cultured by NEM (1.0 mM, $30 \mathrm{~min})$, and then $1(2.0 \mu \mathrm{M}, 5 \mathrm{~min})$. Scale bar: $20 \mu \mathrm{m}$. 


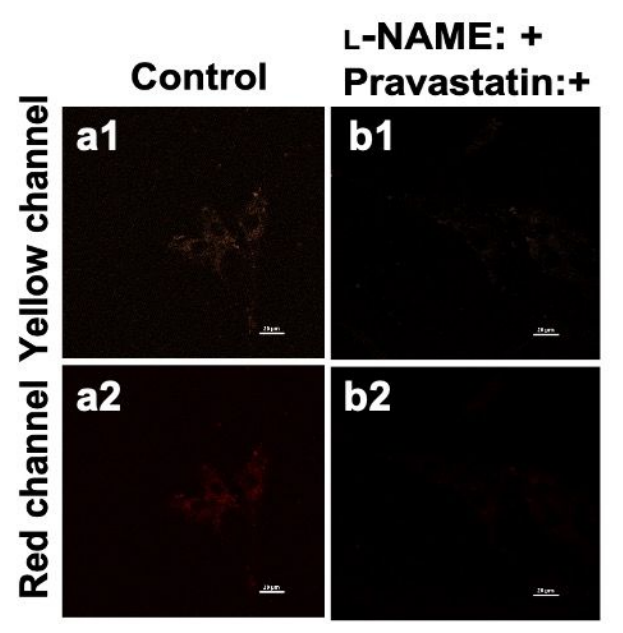

Figure S11. (a1-a2) HUVECs treated with 1 (2.0 $\mu \mathrm{M}, 5 \mathrm{~min})$. (b1-b2) HUVECs pretreated with pravastatin $(0.5 \mathrm{mM}, 12 \mathrm{~h})$, further incubated with L-NAME $(0.5 \mathrm{mM}$, $12 \mathrm{~h})$, then incubated with $1(2 \mu \mathrm{M}, 5 \mathrm{~min})$.

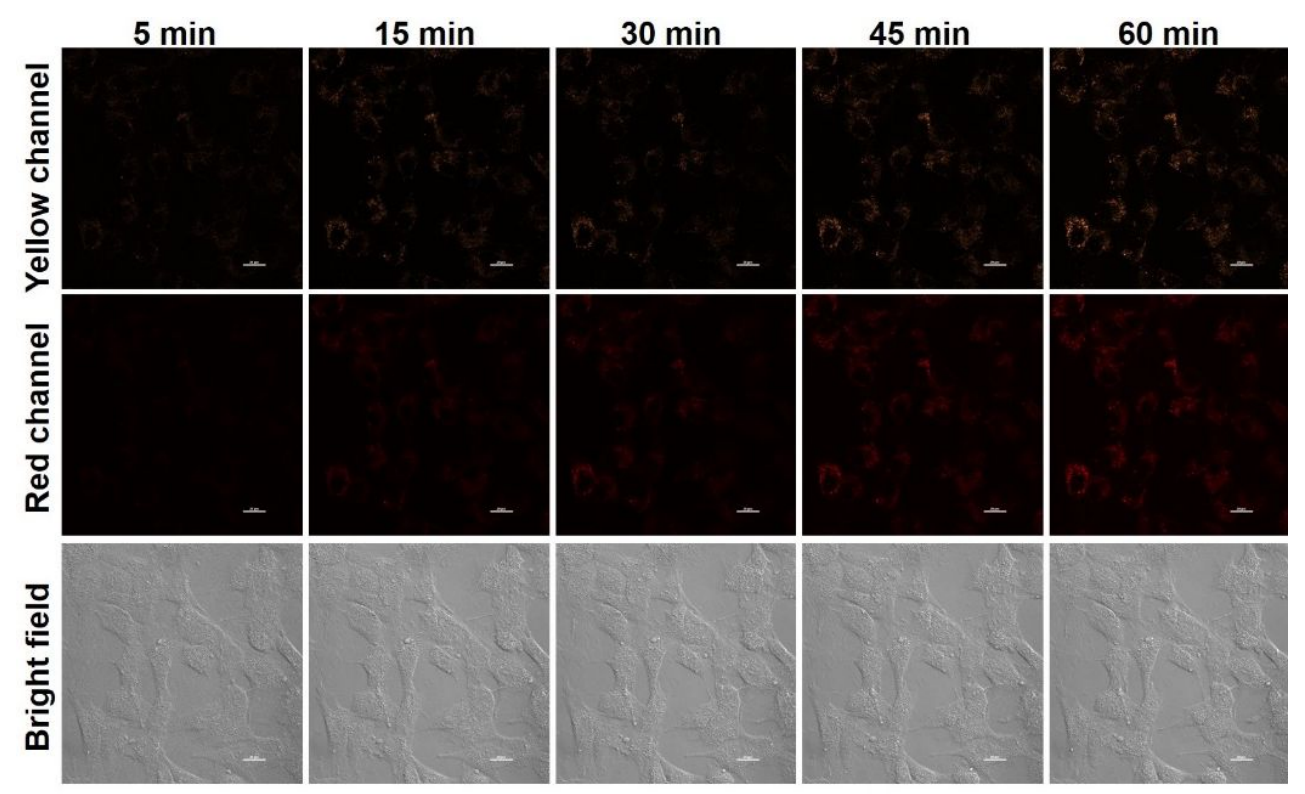

Figure S12. Real-time confocal fluorescence images of HUVECs cultured by BSO $(0.5$ $\mathrm{mM}, 6 \mathrm{~h})$, and then $\mathbf{1}(2.0 \mu \mathrm{M}, 5 \mathrm{~min})$. Scale bar: $20 \mu \mathrm{m}$. 
(a)

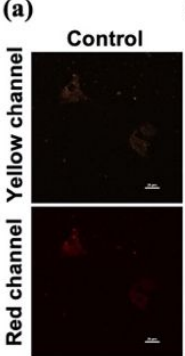

(d)

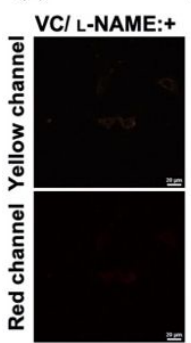

(e)

VC/ BSO:+
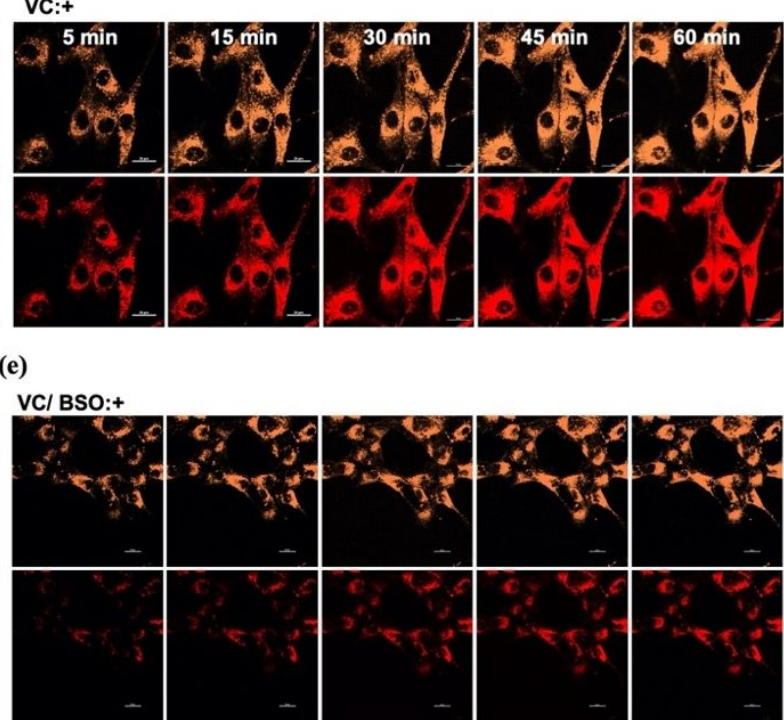

(c)

vC:

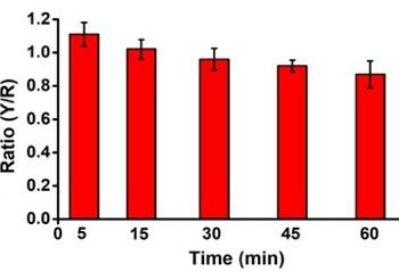
VC/ BSO:+

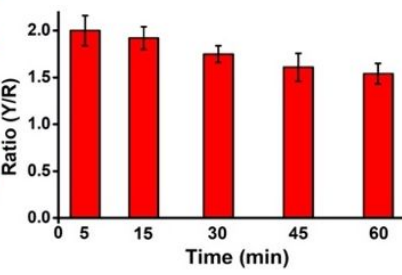

Figure S13. (a) Confocal fluorescence images of HUVECs treated with 1 ( $2.0 \mu \mathrm{M}, 5$ min). (b) Time-dependent confocal fluorescence imaging of HUVECs pretreated with $\mathrm{VC}(0.5 \mathrm{mM}, 12 \mathrm{~h})$, and then cultured with $1(2.0 \mu \mathrm{M}, 5 \mathrm{~min})$. (c) Average fluorescence intensity ratios (yellow/red channels) at different time after incubation with VC and $\mathbf{1}$. (d) Confocal fluorescence images of HUVECs stained with VC $(0.5 \mathrm{mM}, 12 \mathrm{~h}), \mathrm{L}-$ NAME $(0.5 \mathrm{mM}, 12 \mathrm{~h})$, and then $1(2.0 \mu \mathrm{M}, 5 \mathrm{~min})$. (e) Time-dependent confocal fluorescence imaging of HUVECs pretreated with VC $(0.5 \mathrm{mM}, 12 \mathrm{~h}), \mathrm{BSO}(0.5 \mathrm{mM}$, $6 \mathrm{~h})$ and then cultured with $1(2.0 \mu \mathrm{M}, 5 \mathrm{~min})$. (f) Average fluorescence intensity ratios (yellow/red) of HUVECs pretreated with VC $(0.5 \mathrm{mM}, 12 \mathrm{~h})$, further incubated with BSO $(0.5 \mathrm{mM}, 6 \mathrm{~h})$ and then cultured with $1(2.0 \mu \mathrm{M}, 5 \mathrm{~min})$ at different time. Emission was collected at 555-570 nm for yellow channel and at 590-605 nm for red channel (excited at $487 \mathrm{~nm}$ ). Scale bar: $20 \mu \mathrm{m}$.
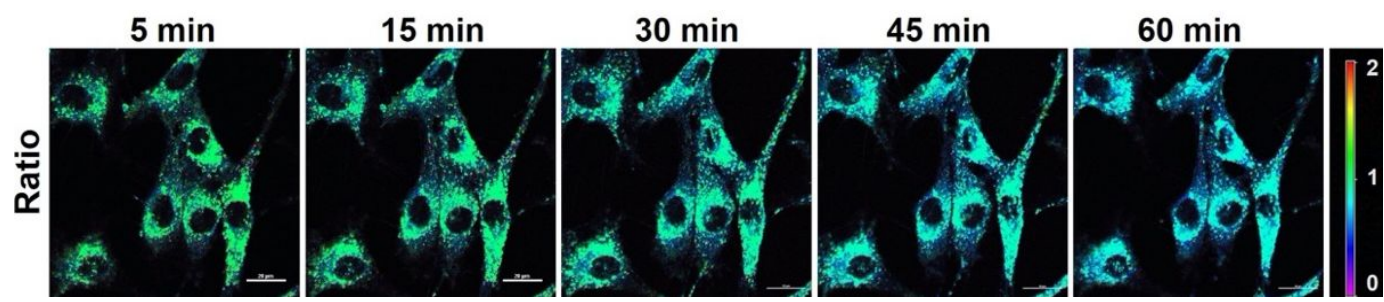

Figure S14. Real-time ratiometric confocal fluorescence images (yellow /red channels) of HUVECs pretreated with VC $(0.5 \mathrm{mM}, 12 \mathrm{~h})$, and then cultured with $\mathbf{1}(2.0 \mu \mathrm{M}, 5$ min). Scale bar: $20 \mu \mathrm{m}$. 


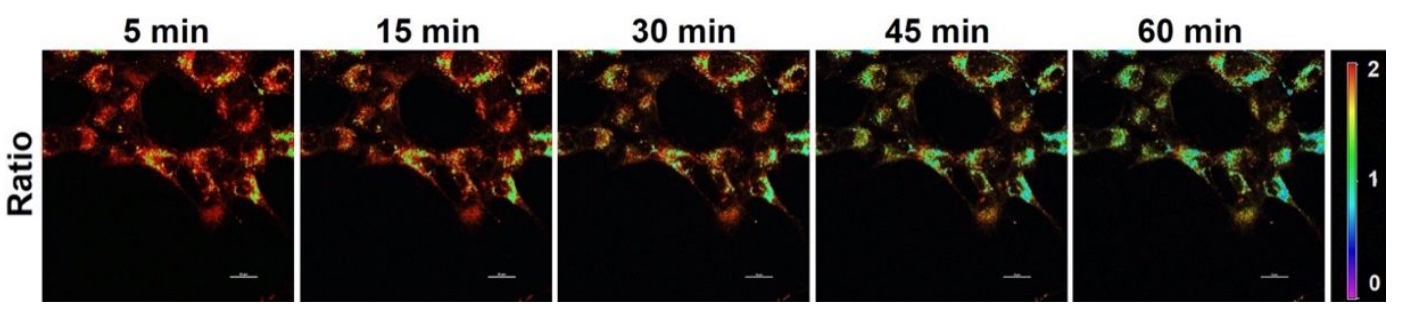

Figure S15. Real-time ratiometric confocal fluorescence images (yellow /red channels) of HUVECs pretreated with VC $(0.5 \mathrm{mM}, 12 \mathrm{~h})$, further incubated with BSO $(0.5 \mathrm{mM}$, $6 \mathrm{~h})$ and then cultured with $1(2.0 \mu \mathrm{M}, 5 \mathrm{~min})$. Scale bar: $20 \mu \mathrm{m}$.

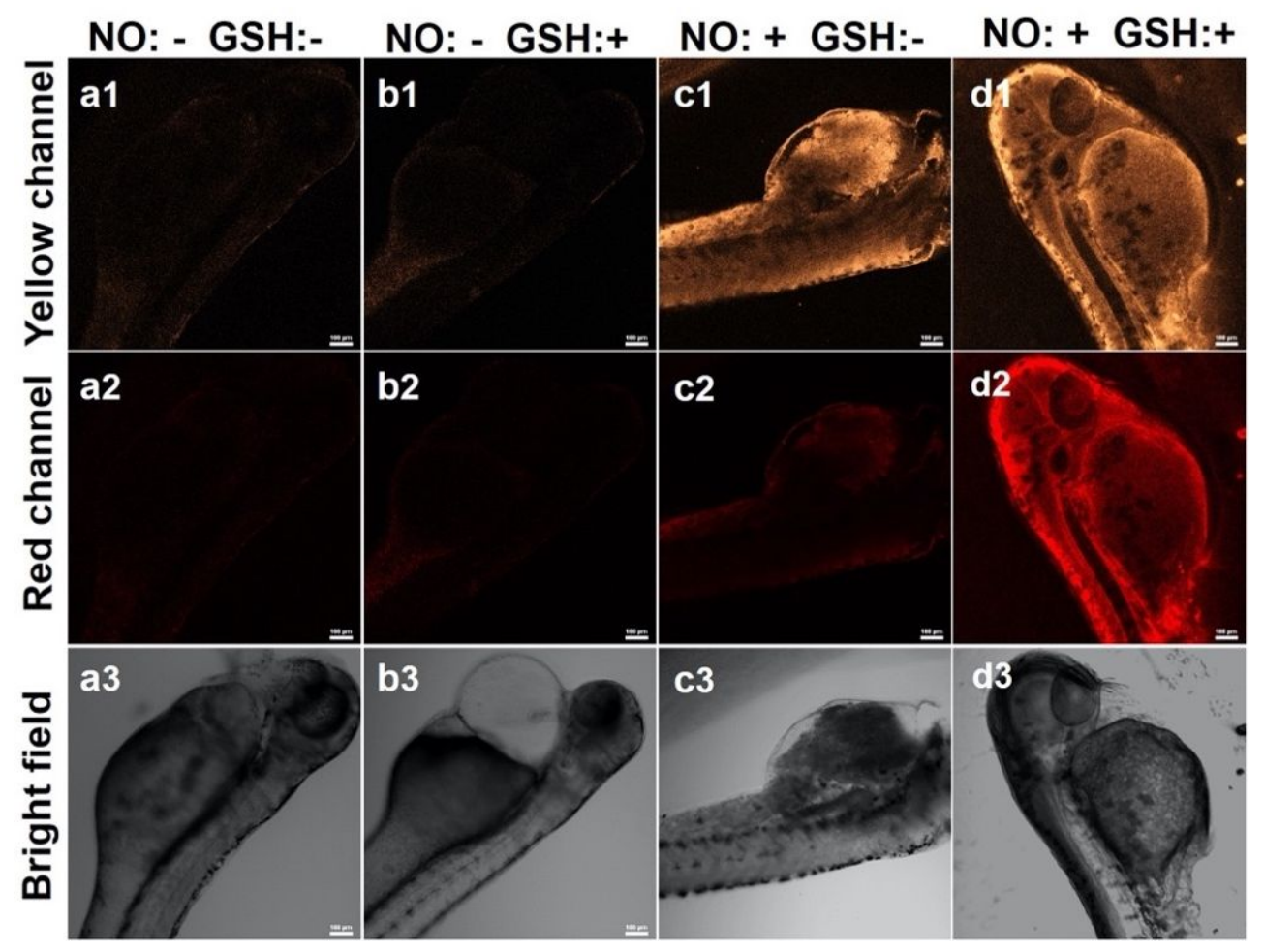

Figure S16. Confocal fluorescence imaging of 1 in the living zebrafish. (a1-a3) 2-dayold zebrafish incubated by NEM $(0.5 \mathrm{mM}, 30 \mathrm{~min})$ and then $1(2.0 \mu \mathrm{M}, 30 \mathrm{~min})$. (b1b3) Zebrafish treated with $1(2.0 \mu \mathrm{M}, 30 \mathrm{~min})$ for $30 \mathrm{~min}$. (c1-c3) Zebrafish cultured by $\operatorname{NEM}(0.5 \mathrm{mM}, 30 \mathrm{~min})$, further incubated with DEA NONOate $(200 \mu \mathrm{M}, 30 \mathrm{~min})$, and then $1(2.0 \mu \mathrm{M}, 30 \mathrm{~min})$. (d1-d3) Zebrafish incubated with DEA NONOate $(200 \mu \mathrm{M}$, $30 \mathrm{~min})$ and then $1(2.0 \mu \mathrm{M}, 30 \mathrm{~min})$. Emission was collected at $555-570 \mathrm{~nm}$ for yellow channel and at $590-605 \mathrm{~nm}$ for red channel (excited at $487 \mathrm{~nm}$ ). Scale bar: $100 \mu \mathrm{m}$. 


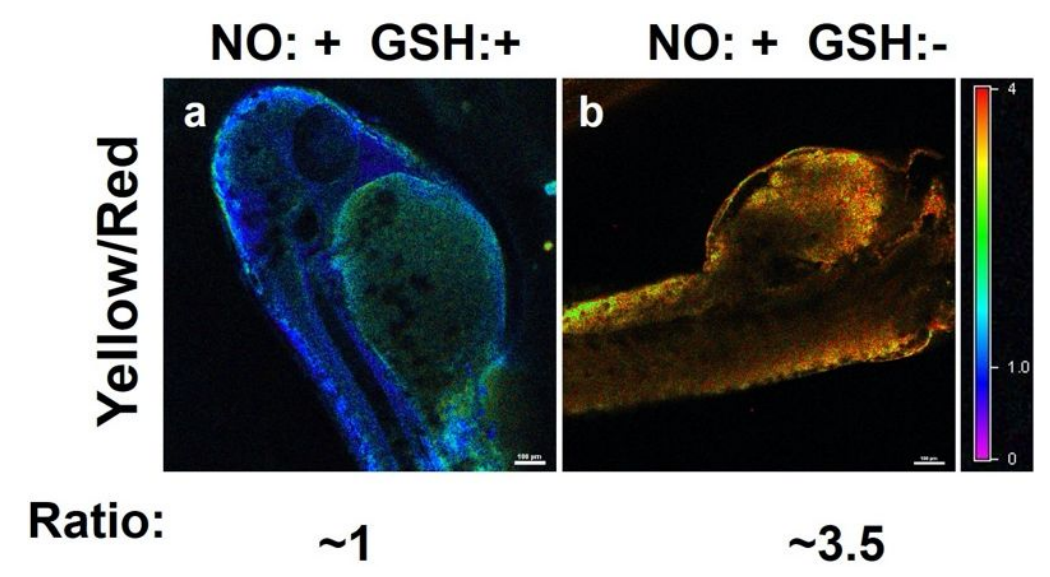

Figure S17. Ratiometric confocal fluorescence images (yellow/red channels): (a) zebrafish cultured by DEA NONOate $(200 \mu \mathrm{M}, 30 \mathrm{~min})$, and then $1(2.0 \mu \mathrm{M}, 30 \mathrm{~min})$. (b) zebrafish cultured by NEM $(0.5 \mathrm{mM}, 30 \mathrm{~min})$, further incubated with DEA NONOate $(200 \mu \mathrm{M}, 30 \mathrm{~min})$, and then 1 (2.0 $\mu \mathrm{M}, 30 \mathrm{~min})$. Scale bar: $100 \mu \mathrm{m}$.

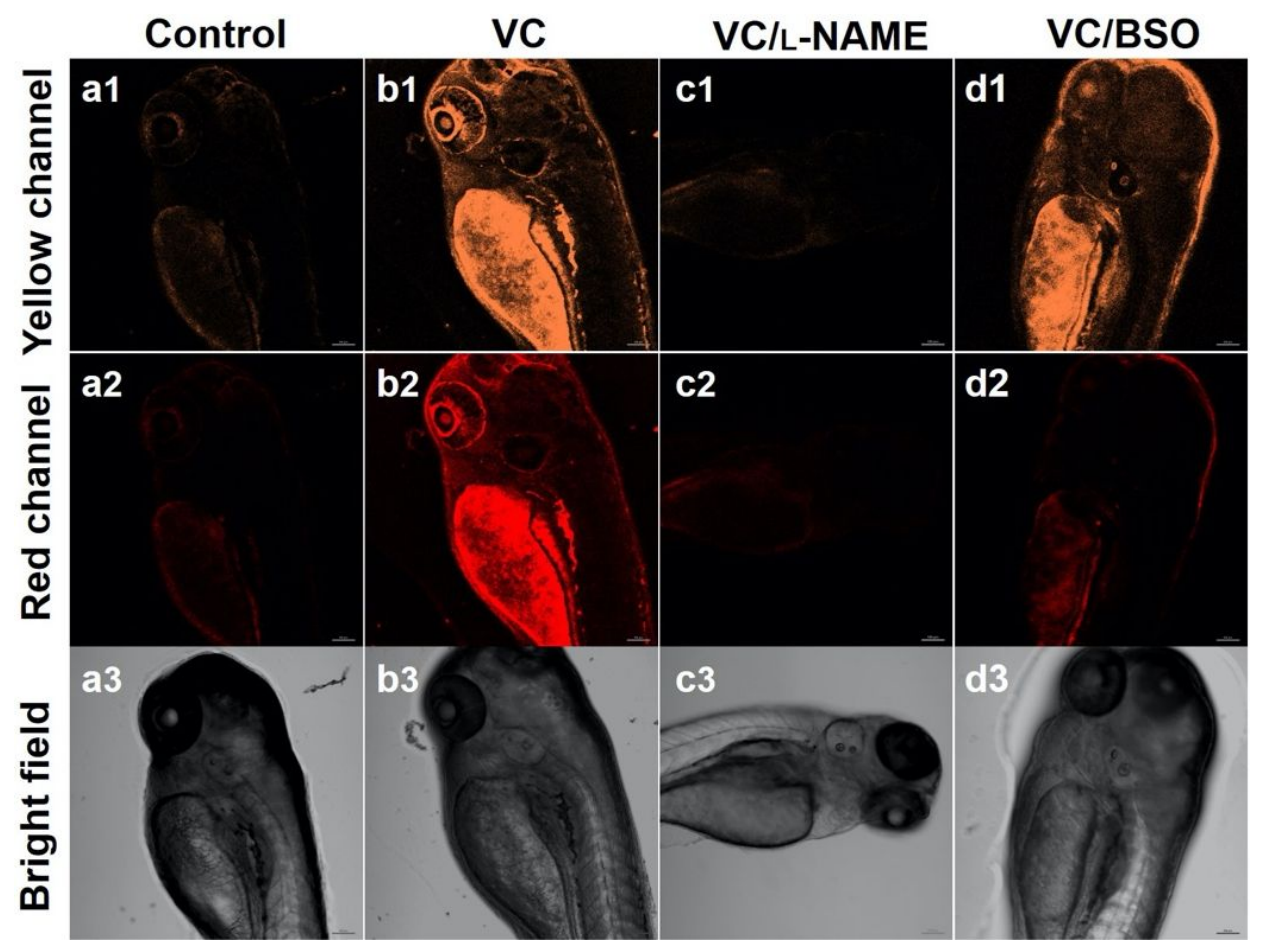

Figure S18. Confocal fluorescence images of 1 in the living zebrafishes. (a1-a3) 2-dayold zebrafish incubated by $\mathbf{1}(2.0 \mu \mathrm{M})$ for $30 \mathrm{~min}$. (b1-b3) Zebrafish treated with VC $(50.0 \mu \mathrm{M}, 24 \mathrm{~h})$, and then $1(2.0 \mu \mathrm{M})$ for $30 \mathrm{~min}$. (c1-c3) Zebrafish cultured by VC $(50.0 \mu \mathrm{M}, 24 \mathrm{~h})$, L-NAME $(100 \mu \mathrm{M}, 12 \mathrm{~h})$ and then $1(2.0 \mu \mathrm{M}, 30 \mathrm{~min}) .(\mathrm{d} 1-\mathrm{d} 3)$ Zebrafish cultured by VC $(50.0 \mu \mathrm{M}, 24 \mathrm{~h})$, BSO $(200 \mu \mathrm{M}, 12 \mathrm{~h})$ and then $\mathbf{1}(2.0 \mu \mathrm{M}$, $30 \mathrm{~min}$ ). Emission was collected at 555-570 nm for yellow channel (excited at $487 \mathrm{~nm}$ ) and at 590-605 $\mathrm{nm}$ for red channel (excited at $487 \mathrm{~nm}$ ). Scale bar: $100 \mu \mathrm{m}$. 


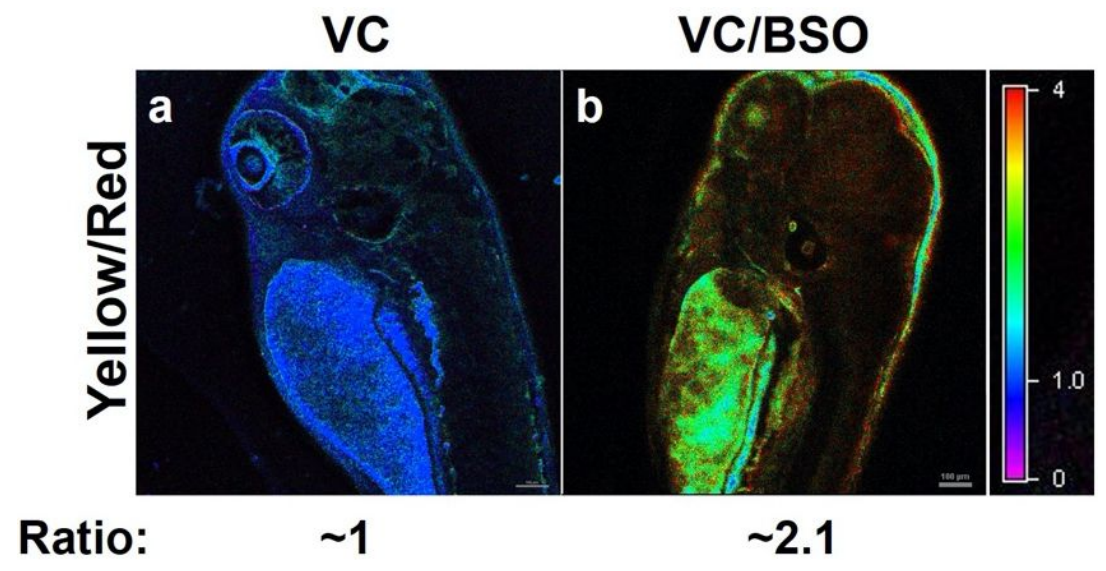

Figure S19. Ratiometric confocal fluorescence images (yellow/red channels): (a) zebrafish treated with $\mathrm{VC}(50.0 \mu \mathrm{M}, 24 \mathrm{~h})$, and then 1 (2.0 $\mu \mathrm{M}, 30 \mathrm{~min})$. (b) zebrafish cultured by VC $(50.0 \mu \mathrm{M}, 24 \mathrm{~h})$, further incubated with BSO $(200 \mu \mathrm{M}, 12 \mathrm{~h})$ and then $1(2.0 \mu \mathrm{M}, 30 \mathrm{~min})$. Scale bar: $100 \mu \mathrm{m}$.

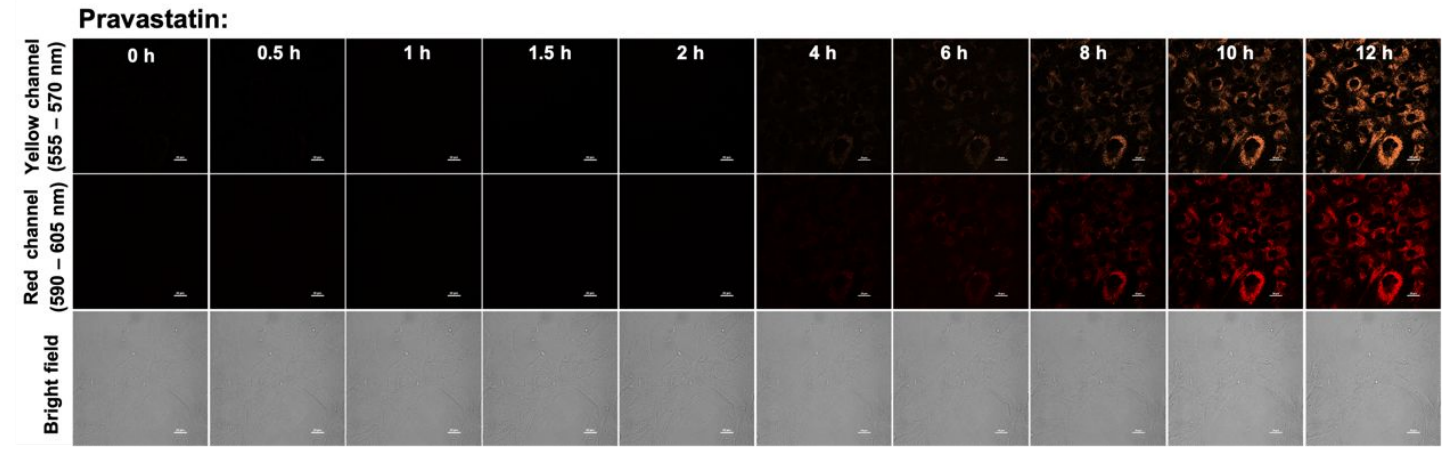

Figure S20. Time-dependent confocal fluorescence imaging of HUVECs pretreated with $1(2.0 \mu \mathrm{M}, 5 \mathrm{~min})$, then incubated with pravastatin $(0.5 \mathrm{mM})$.

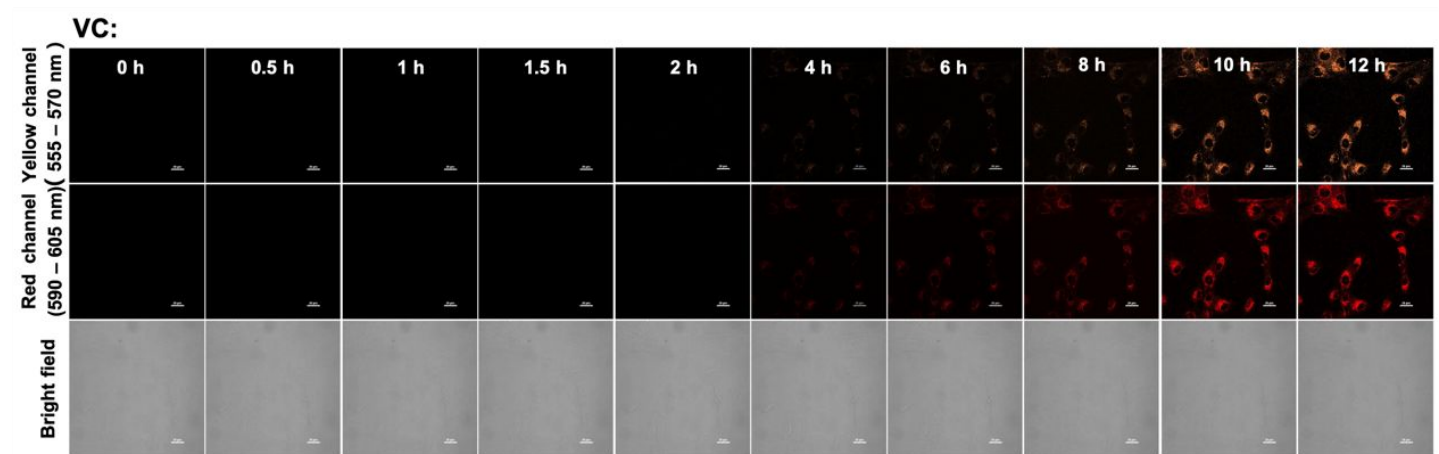

Figure S21. Time-dependent confocal fluorescence imaging of HUVECs pretreated with $1(2.0 \mu \mathrm{M}, 5 \mathrm{~min})$, then incubated with $\mathrm{VC}(0.5 \mathrm{mM})$. 


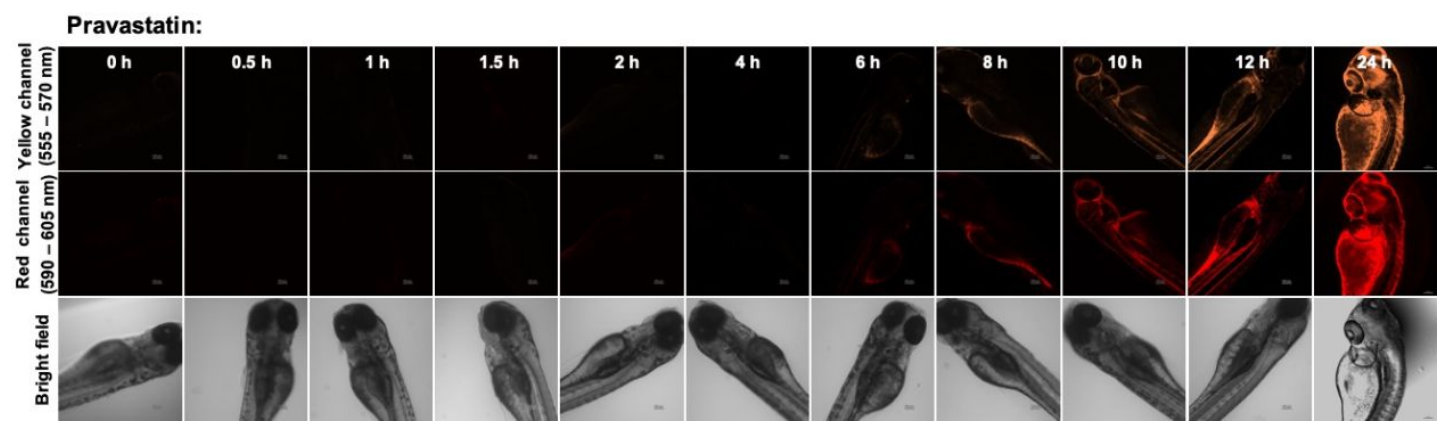

Figure S22. Time-dependent confocal fluorescence imaging of zebrafishes pretreated with $1(2.0 \mu \mathrm{M}, 30 \mathrm{~min})$, then incubated with pravastatin $(0.5 \mathrm{mM})$.

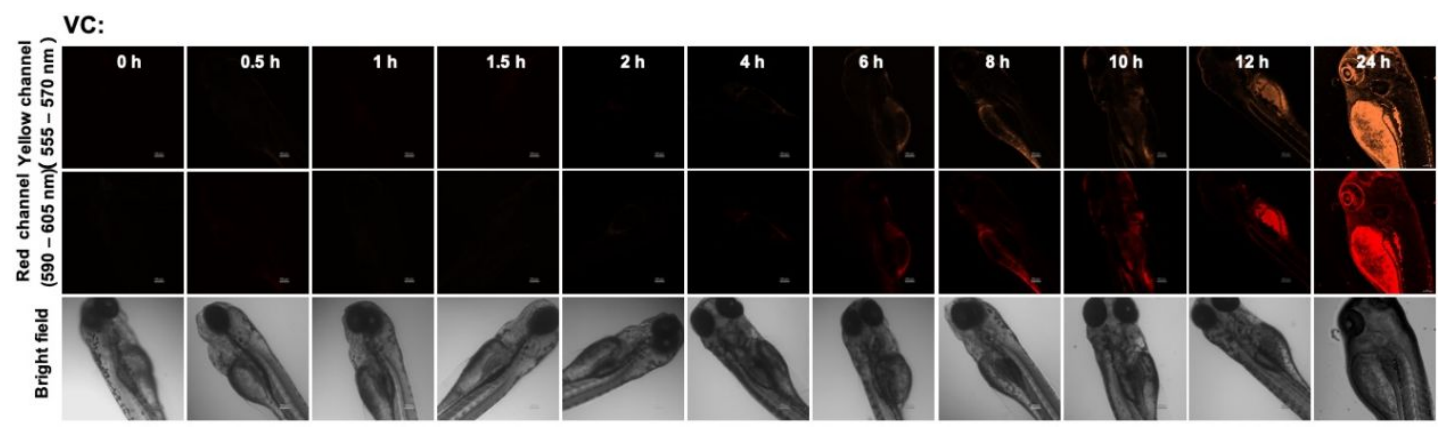

Figure S23. Time-dependent confocal fluorescence imaging of zebrafishes pretreated with $1(2.0 \mu \mathrm{M}, 30 \mathrm{~min})$, then incubated with $\mathrm{VC}(0.5 \mathrm{mM})$.

\section{Reference}

(1) Niu, L.-Y.; Guan, Y.-S.; Chen, Y.-Z.; Wu, L.-Z.; Tung, C.-H.; Yang, Q.-Z., BODIPY-Based Ratiometric Fluorescent Sensor for Highly Selective Detection of Glutathione over Cysteine and Homocysteine. J. Am. Chem. Soc. 2012, 134, 1892818931. 